\title{
第72回日本循環器学会学術集会
}

1. 虚血性僧帽弁逆流の集学的治療

\section{急性心筋梗塞症例における虚血性僧帽弁逆流が 長期予後に与える影響について}

\section{はじめに}

虚血性僧帽弁逆流（ischemic mitral regurgitation: ischemic MR) は, 虚血性心疾患に合併す る僧帽众閉鎖不全である。広義の ischemic MR は乳頭笳断裂を認めるものも含をれるが，狭義の ischemic MR は乳頭筋断裂を認めないものを指 す. 乳頭筋断裂は急性心筋梗塞 (AMI) 後の機 械的合併症の一つであり, 致命的な経過をたど ることが多く, AMI 後のリモデリングの影響で 進行する狭義の ischemic MR とは病態が異なっ ているため, 最近では一般的に ischemic MR と いえば狭義のものを示すことが多い，今回も狭義 の ischemic MRについて検討している。なお， 拆張型心筋症に合併する functional MR も発生機 序が似て抢り同様に扱われることが多いが，拡 張型心筋症のMR では僧帽弁の前尖と後尖が対 称的 (symmetric) であるのに対し, 虚血性心疾 患での MRでは非対称 (asymmetric) であると いう構造上の差を $3 \mathrm{D}$ エコーで比較した報告もあ $ろ^{1)}$.

ischemic MR の原因は，(1)乳頭笳虚血による 乳頭筋不全, (2)AMI 後の左室りモデリングによ る羊輪拡大，(3)リモデリングの影響で乳頭筋が外 側に偏位し，その結果として僧帽弁の弁尖が率引

\author{
大阪警察病院循環器科 \\ 日本大学医学部循環器内科 \\ 大阪警察病院循環器科 \\ 加せがのり \\ 柏 瀬一路 \\ 证やまあっ 立 \\ 元た专のり \\ 上田恭敬
}

される現象（=valve tethering）などが指摘され てきた. Otsuji らは，心房細動症例と虚血性心筋 症症例の比較で, 并輪径が同程度であっても虚血 性心筋症症例のほうが MR が強く観察されるこ とから，ischemic MRの原因は valve tethering の関与が一番大きいと報告している2).

MI 症例における MRの影響については，海外 の報告において，MRの存在が MI の予後の増悪 因子であるということは示されているが3〜5)，再 灌流療法の施行率が本邦に比べて低く, ST 上昇 を伴う急性心筋梗塞 (STEMI) 症例の率が低い などの違いがある.さらに，重症の MR も含めて の検討であるため, ischemic MR たけではなく 乳頭筋断裂や器質性の MR を含んでいる可能性 がある.今回，われわれはAMIの急性期を離 脱しても MR が残存している症例，すなわち ischemic MRがあることが予後に影響するかを 検討するために，当院における STEMI 症例の追 跡調査のデータを報告する.

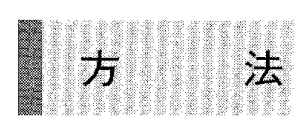

\section{1. 対 象}

1998年 4 月から 2005 年 11 月までに当院に STEMI で入院し，発症 1 力月後に心エコー図検 
表 1 患者背景

\begin{tabular}{|c|c|c|c|c|}
\hline 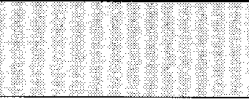 & $\begin{array}{l}n o \mathrm{MR} \\
(n=270)\end{array}$ & $\begin{array}{l}\text { mild MR } \\
(n=204)\end{array}$ & $\begin{array}{l}\text { moderate MR } \\
(n=76)\end{array}$ & P value \\
\hline 年 齢 & $63 \pm 11$ & $67 \pm 10$ & $71 \pm 10$ & $p<0.01$ \\
\hline 男 性 & $215(79.6 \%)$ & $160(78.4 \%)$ & $48(63.2 \%)$ & $p<0.05$ \\
\hline 糖尿病 & $81(30.0 \%)$ & $77(37.7 \%)$ & $21(27.6 \%)$ & n.s. \\
\hline 高血圧 & $139(51.5 \%)$ & $100(49.0 \%)$ & $49(64.5 \%)$ & $p<0.05$ \\
\hline 高脂血症 & $112(41.5 \%)$ & $82(40.2 \%)$ & $17(22.4 \%)$ & $p<0.05$ \\
\hline 喫 煙 & $182(67.4 \%)$ & $118(57.8 \%)$ & $40(52.6 \%)$ & $p<0.05$ \\
\hline RCA & $48 \%$ & $49 \%$ & $44 \%$ & n.s. \\
\hline LAD & $39 \%$ & $42 \%$ & $44 \%$ & n.s. \\
\hline LCX & $17 \%$ & $16 \%$ & $28 \%$ & n.s. \\
\hline 心筋梗塞の既往 & $10(3.7 \%)$ & $35(17.2 \%)$ & $19(25.0 \%)$ & $p<0.01$ \\
\hline 発症前の胸痛 & $70(25.9 \%)$ & $43(21.1 \%)$ & $21(27.6 \%)$ & n.s. \\
\hline 来院時 Killip $\geqq 2$ & $12(4.4 \%)$ & $31(15.2 \%)$ & $15(19.7 \%)$ & $p<0.01$ \\
\hline $\mathrm{CK} \geqq 3,000 \mathrm{IU} / \mathrm{I}$ & $61(22.6 \%)$ & $66(32.4 \%)$ & $25(32.9 \%)$ & $p=0.06$ \\
\hline 再灌流療法 & $241(89.3 \%)$ & $186(91.2 \%)$ & $62(81.6 \%)$ & $p=0.07$ \\
\hline
\end{tabular}

查を実施した連続550症例を対象とした。1 1 月 後の心エコー図検査において，カラードプラによ り MRの重症度を評価して, no MR（grade 0： 270症例), mild MR (grade 1:204症例), moderate MR (grade 2 3:76症例) の 3 群に分類し た。その際，僧帽弁の逸脱やリウマチ性変化など 器質性 MR 認める症例, 乳頭筋断裂の症例, grade 4 の severe MR を認める症例は検討から 除外した。

\section{2. 予後調査}

予後調査はアンケートや電話調査で行い, primary endpoint 非致死性再梗塞や心不全入院として平均752日間 の追跡調查を行った。予後追跡率は95\%であっ た.

\section{3. 評価項目, 統計解析}

評価項目江年齢, 性別, 糖尿病, 高血圧, 高脂 血症，契煙歴，心筋梗塞の既往，Killip 分類，梗 塞部位，peak CK，再灌流療法を評価した。評価 項目の群間差についての統計学的考察は, 連続変 数については $t$ 検定, カテゴリ一变数については $\chi^{2}$ 検定を利用した. 生存曲線は, カプランマイ ヤー法にて作成し, 各群の生存率の差はログラン クテストで評価した。また，各群の全死亡・心不 全入院に対する相対危険度の算出には Cox 回帰

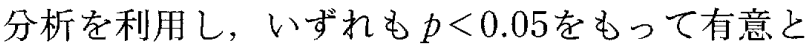
した。

\section{結 果}

\section{1. 患者背景}

表 1 に no MR, mild MR, moderate MR 各群の 患者背景を示す．MRの重症度が増すにしたがっ て，(1)年齢が高い，(2)女性の割合が増える，(3)高 血压の合併が増える，(4)高脂血症の合併が減る， (5)契煙歷を有する割合が減る，(6)心筋梗塞の既往 がある症例（再梗塞症例）が増える，(7)来院時の Killip 分類が 2 度以上の心不全の合併症例が増え 
表 2 MR 重症度が心血管イベントに及ぼす影響（単変量解析）

\begin{tabular}{c|c|c|c|c}
\hline & $\begin{array}{c}\text { no MR } \\
(n-270)\end{array}$ & $\begin{array}{c}\text { mild MR } \\
(n=204)\end{array}$ & $\begin{array}{c}\text { moderate MR } \\
(n-76)\end{array}$ & $p$ value \\
\hline primary endpoint & & & & \\
全死亡 & $3(1.1 \%)$ & $19(9.3 \%)$ & $18(23.7 \%)$ & $p<0.01$ \\
\cline { 1 - 1 } secondary endpoint & & & & \\
心不全入院 & $2(0.7 \%)$ & $17(8.3 \%)$ & $15(19.7 \%)$ & $p<0.01$ \\
非致死性再梗塞 & $7(2.6 \%)$ & $16(7.8 \%)$ & $3(3.9 \%)$ & $p<0.05$ \\
\hline
\end{tabular}

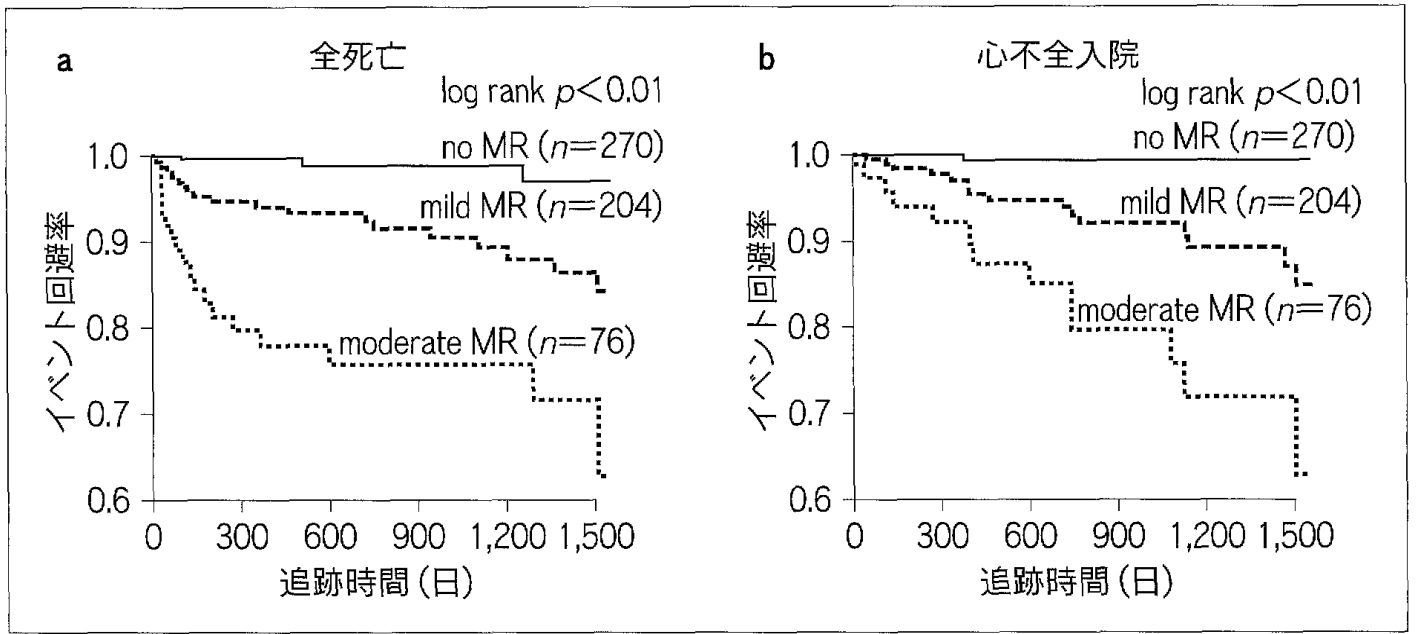

図 1 全死亡と心不全入院の推移

る，という要素が統計的に有意な因子として抽出 された．再灌流療法は全症例の $89 \%$ に施行され， 群間で有意差を認めなかった。

\section{2. 予後調査}

表 2 に primary endpoint の全死亡, secondary endpoint の非致死性再梗塞や心不全入院の単変 量解析での結果を示す. 全死亡と心不全入院の出 現率は，MRの重症度が増すにしたがって有意に 増加した（図 1). 非致死性再梗塞の発症は mild MR 群が有意に高いものの, 各群間の差は小さい ことから MRの寄与は低いと考えられた。

全死亡と心不全入院の出現については，さらに 多变量解析を行った。 Cox 回帰分析にて，心筋 梗塞の予後の増悪因子と指摘されている年齢, 性 別, 糖尿病, 高血圧, 高脂血症, 哭煙歴, BMI, 心筋梗塞，来院時に Killip 分類 2 度以上の心不全
表 3 MR 重症度が心血管イベントに及ぼす影響 (Cox 回帰分析による検討)

\begin{tabular}{l|ccc}
\hline & hazard ratio & $95 \%$ 信頼区間 & $p$ value \\
\hline 全死亡 & \multicolumn{4}{c}{. } & & \\
no MR & 1 & reference & - \\
mild MR & 1.15 & $1.01-2.30$ & 0.03 \\
moderate MR & 3.72 & $1.81-7.64$ & $<0.001$ \\
\hline 心不全入院 & & & \\
no MR & 1 & reference & - \\
mild MR & 1.77 & $0.64-9.15$ & 0.11 \\
moderate MR & 4.06 & $1.52-10.8$ & $<0.01$ \\
\hline
\end{tabular}

の合併, 再灌流療法施行, peak CK が3,000 IU /l 以上という因子で補正を行ったところ，全死亡は MRの重症度が増すにしたがって有意に増加した （表 3）。また，心不全入院の出現については no MRに比べると mild MR は有意な因子として抽 
出されなかったが, moderate MR は有意な危険 因子として抽出された。これらの現象について は, 再灌流療法としてPCI を施行した384症例に ついて検討しても同様の結果となった.

\section{考察}

AMI 症例の長期予後において, ischemic MR の存在が予後の増悪因子であるという報告は以前 よりいくつかなされている.

Grigioni らが，MIの慢性期の5年間のフォ ローでMRがある症例は, ない症例よりも予後 がわるいという報告をしている3゙.ここでは，冠 動脈造影の所見や再灌流療法の有無のデータは 示されていない。また, Hillisらが737人の MI 患者のフォローのデータを報告しており, 単変 量解析では MRの重症度が増すほど予後が悪化 したが，多变量解析では軽度のMR 群とMRな し群では予後に差を認めなかった

STEMI が各群とも50\%前後であり，血栓溶解療 法実施が $20 \%$ 前後, primary PCI 実施も20\%前 後である. 本邦では, MI 症例, とくに STEMI 症例の治療に抢いては緊急冠動脈造影や再灌流療 法の実施率が高いという特徽があり，これらの報 告の $\mathrm{MI}$ 症例の分布と本邦の $\mathrm{MI}$ 症例の分布とは 異なる点が多い。

これに対し, Pellizzonらは, 発症12時間以内 のMIに対して primary PCIを行ったCADILLAC trial のサブ解析で, 左室造影による MRの 評価を行ったところ，1年生存率において moderate to severe MR も mild MR も独立した予後の 増悪因子であったと報告している5). primary PCI を行った症例に限定していることから, 今回 の検討と患者背景は近いと考えられる. 発症早期 の左室造影による MRの評価であり, MRの原 因の区別はなされず乳頭筋断裂などの重症例を含 んでいる可能性があることや，30日生存率の段 階で差が付いていることから，1年後の生存率の 評価にも30日以内の早期死亡が影響している可 能性がある。
今回の検討では, 発症 1 力月後の心エコー図 で重症度を分けて打り，30日以内の死亡例や乳 頭管断裂の合併症例などを除外した。再灌流療法 施行症例では，残存虚血の影響が低く, ischemic MR の発生機序において乳頭笳不全の影響が少な い，すなわち valve tethering による ischemic MR の予後への影響をより反映していると考えられ る。ただし，カラードプラによる重症度分類で検 討しており， valve tethering を直接評価していな いため, 今後その点についてさらに検討が必要で ある。

今回の検討において, moderate MR は全死亡 や心不全入院の独立した危険因子であることと， mild MR が全死亡の独立した危険因子であるこ とが示された，症例数が増加すれば， mild MR でも心不全入院の危険因子となりうると推測され る。そのようにMRを合併する症例において は，利尿薬等を含めた内服治療の強化が必要であ る. 心不全を呈する症例では, Dor 手術やSAVE 手術などの左室形成術6) と僧帽弁輪形成術を検討 するべきである．最近では乳頭筋間の拡大例で は, tethering 改善のために両側の乳頭筋を縫縮 する術式も報告されている7). mild MR は従来, 病的意義は低く，とくに処置を要しないと扱われ てきたが，リモデリングによる心拡大の影響にさ らにプラスアルファの影響を与えている可能性が ある、このような症例に左室形成術を行う際に は，并輪形成術を行うことも検討するべきであろ う.いずれにしても，ischemic MR 以外の MR の手術基準よりも，より早期に，より軽症の段階 から手術を考慮すべきであり，適応基準が今後変 更されていく可能性が高いと考えられ，今後も治 療データの蓄積が必要である.

\section{おわりに}

心筋梗塞の慢性期において，MR を有する症例 は，それが軽度であっても予後不良である，内服 の強化や手術を考慮して，心不全発症や心蔵死を 防ぐ必要がある。 


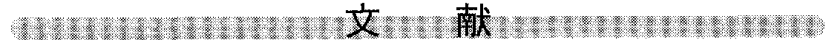

1) Kwan J, Shiota T, Agler DA et al: Geometric differences of the mitral apparatus between ischemic and dilated cardiomyopathy with significant mitral regurgitation: real-time three-dimensional echocardiography study. Circulation 2003; 107: 1135-1140

2) Otsuji $\mathrm{Y}$, Kumanohoso T, Yoshifuku $\mathrm{S}$ et al: Isolated annular dilation does not usually cause important functional mitral regurgitation: comparison between patients with lone atrial fibrillation and those with idiopathic or ischemic cardiomyopathy. J Am Coll Cardiol 2002; 39: $1651-1656$

3) Grigioni F, Enriquez Sarano M, Zehr KJ et al: Ischemic mitral regurgitation: long-term outcome and prognostic implications with quantitative Doppler assessment. Circulation 2001; 103: 1759-1764

4) Hillis GS, Moller JE, Pellikka PA et al: Prognostic significance of echocardiographically defined mitral regur- gitation early after acute myocardial infarction. Am Heart J 2005; 150: 1268-1275

5) Pellizzon GG, Grines CL, Cox DA et al: Importance of mitral regurgitation inpatients undergoing percutaneous coronary intervention for acute myocardial infarction: the Controlled Abciximab and Device Investigation to Lower Late Angioplasty Complications (CADILLAC) trial. J Am Coll Cardiol 2004; 43: 1368-1374

6) Dor V, Sabatier M, Di Donato $M$ et al: Efficacy of endoventricular patch plasty in large postinfarction akinetic scar and severe left ventricular dysfunction: comparison with a series of large dyskinetic scars. J Thorac Cardiovasc Surg 1998; 116: 50-59

7) Menicanti L, Di Donato M, Frigiola $\mathrm{A}$ et al: Ischemic mitral regurgitation: intraventricular papillary muscle imbrication without mitral ring during left ventricular restoration. J Thorac Cardiovasc Surg 2002; 123: 10411050

\section{用圄獬說}

\section{ダブルチェーンドメイン（DCD）}

アンジオテンシンII 1 型 (AT1) 受容体ブ ロッカー (ARB) は，日本において 6 種類が 発売され，降圧のみでなく，心・腎・脳保護 作用を有している。ほとんどの ARBは，化 学構造上の共通した特徵として，イミダゾ一 ル基とビフェニールテトラゾール基を含んで いる.

ARBの中でも olmesartan は，降圧効果に 優れた ARB であり，上記の共通した化学構 造以外に，その側鎖にカルボキシル基とヒド ロキシル基を有し，他の ARB にはない化学 構造上の特徵を有している.この2つ(ダブ ル）の基は, AT1 受容体側のアミノ酸と特異
的に鎖（チェーン）のように強固な結合を示 し，この領域（ドメイン）のことをダブルチ ェーンドメイン (DCD) と呼んでいる (Miura S et al: Curr Hypertens Rev 2005)．さらに, DCD は， olmesartan がインバースアゴニズ ム（逆アンジオテンシンIII作用）を発揮する 場合にも重要であるといわれており（Miura S et al: J Biol Chem 2006), olmesartan の降 圧効果が優れている一つの理由と考えられて いる.

（福岡大学心臓・血管内科学

$$
\text { 㱏浦伸一郎，幛 㤵二郎) }
$$

